\title{
The Effect of Statutory Sanctions on Management of Trade Disputes in Nigeria: A Critical Appraisal
}

\author{
Francis C. Anyim \\ Department of Industrial Relations and Personnel Management \\ Faculty of Business Administration \\ University of Lagos, Nigeria \\ Tel: +80-334-68317Ｅ-mail: chucksanyim2004@yahoo.com \\ Cyril Oseloka Ikemefuna (Corresponding author) \\ Department of Industrial Relations and Personnel Management \\ Faculty of Business Administration \\ University of Lagos, Nigeria \\ Tel: +80-230-40845Ｅ-mail: cyikem-unilag@yahoo.co.uk \\ Oluwakemi Ayodeji Owoyemi \\ Department of Industrial Relations and Personnel Management \\ Faculty of Business Administration \\ University of Lagos, Nigeria
}

Tel: +23-480-5659-5701Ｅ-mail: oluwakemi.owoyemi@yahoo.com

\author{
Received: August 16, 2011 \\ Accepted: Septmber 7, 2011 Published: November 21, 2011 \\ doi:10.5430/ijba.v2n4p155 \\ URL: http://dx.doi.org/10.5430/ ijba.v2n4p155
}

\begin{abstract}
A cursory look at the Trade Disputes Act in Nigeria shows that the Act did not specifically remove the right of workers to strike but in practical terms it is absolutely impossible for workers to embark on strike if all the provisions outlined in the Act including statutory sanctions are diligently and faithfully followed at appropriate times. In spite of these practical difficulties or constraints and other measures taken by government to minimize industrial disputes, evidence abound that strikes have been occurring in large number in both public and private sector of the economy irrespective of the institutional framework put in place for disputes settlement. This study is an attempt at assessing the impact of statutory sanctions on the number of disputes reported. In other words, has the sanctions met its intended objectives in terms of curtailing the number of disputes or otherwise. Trade unions in two sectoral groups: oil and gas and tertiary institutions in the educational sector where industrial strife has been on a high side were drawn as samples for the study. The findings from the study revealed that the imposition of statutory sanctions has no significant effect on the number of disputes reported. Besides, government seldom invokes the sanctions when parties breach the Act. The way forward or measures to make the sanctions more effective and result-oriented were proposed to guide policy makers and other stakeholders involved in trade disputes management.
\end{abstract}

Keywords: Statutory Sanctions, Management of Trade Disputes, Critical Appraisal

\section{Introduction}

It is generally believed that an industrial relations system is derived from the particular political, economic, legal or other contexts within which it exist. These contextual factors play prominent roles in shaping the direction of industrial relations. In many industrialised and developing countries of the world, the industrial relations have emerged from the British model. However, with time each country continues to fashion its system to meet its specific needs. 
Between 1960 and 1966, industrial relations system in Nigeria was based "Laissez-faire" doctrine or voluntary ethic. According to Yesufu (Yesufu, 1982), the state under this doctrine did not intervene directly in the employment contract or in determining working conditions rather the interaction of the forces of demand and supply was left to set wages and prevailing working conditions at economically and socially acceptable levels, for both workers and employers. However, during the civil war (1967 to 1970) in Nigeria, industrial relations policy shifted from Laissez-faire doctrine to the direction of greater state intervention and control. The period witnessed fundamental changes in the role of government in industrial relations. Government abandoned its back bench for a more positive approach in handling the increasing number of industrial strife in the face of national emergency which threatened the corporate existence of the country. Strikes were banned. The procedure for declaring trade disputes was made more cumbersome and law enforcement agents were empowered to arrest and detained recalcitrant trade union officials as well as proscribe unions. As Fajana (2000) puts it, the new philosophy of government in labour relations which stipulates the right of government to intervene in both union and management and union-management relations is coined the principle of "limited intervention and guided democracy”. The policy became necessary due principally to the chaotic trade union and industrial relations situation in the country before the inception of the new policy (Fashoyin, 1980) .However, Otobo (1987) argues that the intention of the military regime that engineered the policy was in fact not just to discipline the unionists but also to achieve some objectives that are not connected with controlling the labour movement by incorporating it within state apparatus.

In the light of the foregoing, government shifted from its non-interventionist policy to that greater intervention for reasons already adduced and this government position has remained so to the present day. Currently, the legislation promulgated by government for the management of trade disputes in Nigeria is enshrined in Trade Disputes Act CAP T8 Laws of the Federation of Nigeria, 2004. Section 7 of the Act states that any act in breach of the terms of settlement by a conciliator appointed by the Minister of Labour and Productivity is an offence punishable in the case of worker or the workers' union, with a fine of N200 (two hundred Naira) but in case of an employer or employers' union with a fine of N2000 (two thousand Naira).

Section 17 of the Act in equal vein prohibits strikes and lockouts where there is a trade dispute and a mediator has not been appointed or the Minister has taken steps to refer the dispute to a conciliation, the Industrial Arbitration Panel (IAP) or the National Industrial Court (NIC), declaring or taking part in a strike or lockout is an offence punishable with a fine of N100 (one hundred Naira) or imprisonment for 6 months in the case of an individual or in the case of a corporate body to a fine of N1000 (One thousand Naira).

Section 42 of the Act has it that any worker who takes part in a strike is not entitled to any wages or other remuneration for the period of the strike and the period of the strike shall not count for the purpose of reckoning the period of continuous employment. Section 42 goes further to state that any worker locked out by the employer shall be entitled to wages for the period of the lockout.

Section 18 made it an offence to grant general or percentage wage increase to employees without the approval of the Minister. So strict the punishment that an individual on conviction can be imprisoned for (three) 3 years, while a corporate body will pay $\mathrm{N} 25,000$ (Twenty five thousand Naira). Even IAP and NIC cannot grant general or percentage wage increase without the approval of the minister.

In a nutshell, the study intends to examine why in spite of the foregoing statutory sanctions put in place to minimize disputes, the phenomenon has been on the increase on a consistent basis. However, it is pertinent to state that sanctions examined in this study exclude employees in the Essential Services.

\section{Literature Review}

The government plays the role of an employer and an arbiter in the relationship between the employers and workers in an industrial setting. It provides the legal framework by setting the web of rules and regulations that guide and govern the conduct of the parties in industrial relations. As a referee in the system, government must legislate in order to ensure harmony of conflicting social forces and interests in the system. Every government whether democratic or authoritarian, socialist or capitalist, military or civilian has the prime responsibility of ensuring peace, stability and harmony in the economy. No responsible government can afford the dangerous luxury of paying lip service to industrial stability (Fajana, 2000). Most often state authorities lay down the laws and regulations within which industrial relations operated and those directly pertaining to industrial and labour relations matters are collectively known as" labour laws” (Otobo, 2007). Industrial conflict as a phenomenon tends logically to be inevitable, but there are machineries to ensure that it is accommodated by way of individual resolution, apprehension by the state, unilaterally by government or joint resolution through collective bargaining by parties (Anyim, 2009). 
Industrial or trade disputes has both costs and benefits to all and they draw attention to the interactional relationship between government, labour and management. To a large extent they have a great bearing on the smooth and orderly development of the economy and maintenance of law and order in the society. They sometimes arouse public resentment because they may hurt the public more than the parties involved in the dispute. The proper functioning of industrial relations and collective bargaining defenps on the existence of a legal framework provided by the state. The legal framework determines the type of industrial atmosphere the nation desires and the unit of disruption allowed in the process of industrialization between labour and management (Fajana, 2000). Iwuji (Iwuji, 1987) sees the provisions on disputes resolution as a child of necessity and also an attempt at peaceful settlement trade disputes which are intended to avoid a situation where unions and employers both seeking to, further their interest by coercion and violence threaten the maintenance of law and order or even destroy the system.

Borishade (1990) observes that prior to 1976, trade disputes in Nigeria were treated as part of the common law of contract and were accordingly dealt with in the ordinary civil law courts. However, due to the oil boom and the consequent rapid growth in commercial and industrial activities, labour problems became more complex than the ordinary courts could satisfactorily cope with and consequently, government decided to set up a separate machinery for settling trade disputes. The Trade Disputes Act deals with internal resolution of conflicts among parties while the external machinery is covered by legal provisions in the Act. The external disputes procedures is expected to be voluntarily pre-agreed and self imposed undertaking by the parties to resolve grievances through specified machinery without resort to industrial action in the first instance. It is when the parties have exhausted the internal machinery to no avail that the external machinery is resorted to (Otobo, 2007). The external mediation which is not part of the statutory procedure could be used by parties. In Nigeria, the Trade Disputes Act makes it compulsory for managements and unions to stipulate in their collective agreements the various stages involved in processing grievances and settling disputes (Otobo, 2007).

If the dispute is not settled within the specified or demarcated period of time, the Minister is empowered to refer the dispute after due process for conciliation, arbitration (IAP) adjudication (NIC) or appoint a Board of Inquiry as the case may be (Anyim, 2009). Conciliation as a process of peace - making in industrial relations aims to bring about the speedy settlement of disputes without resort to strikes or lockouts and hasten the termination of work stoppages when these have occurred (Otobo, 2005). Arbitration has been defined as a procedure for the settlement of disputes under which the parties agree to be bound by the decision of an arbitrator whose decision is in general final and legally binding on both parties (Orojo \& Ajomo, 1999). Aturu (2001) questions the overbearing power of the Minister by stating that under Section 18 of the Trade Disputes Act, the powers given to the Minister are too many. He wields so much power that it is unsafe to entrust to one person. According to Aturu (2001), queries have been raised as to why the Minister must confirm an IAP award before it would become binding. Furthermore, why should parties go through the tedious process of resolution up to arbitration only for the Minister to refuse to confirm the award. Fashoyin (1992) observes that trade unions tend to prefer arbitration to conciliation, especially where interest disputes or economic issues are involved. Ubeku (1986) laments that IAP out of enthusiasm sometimes hands down decision not in accord with the practice in the industry. For instance, he states that the backdating of award on arrears appears inconsistent with the provisions of the government income polices. On adjudication, Odumosu (1987) states that the faulty is not always on one side and that the machinery is by no means perfect. He went further to ask if there as anything devised by human ingenuity that is ever flawless but dare say there is none.

\section{Methodology}

\subsection{Sample}

The sample for the study were drawn from two sectoral groups: trade unions in oil and gas and tertiary institutions in the educational sector for their coverage and being sectors plagued by disputes than any other in Nigeria. It would have been difficult to cover all sectors, hence representative samples. However, the two groups cover some 420,000 union members representing about $15 \%$ of organised labour force in Nigeria.

Due to the diverse nature of the two groups, stratified random sampling technique was used to obtain a sample of 230 respondents out of a population of 2200 elements from the oil and gas industry and 470 out of the 3100 from the tertiary institutions.

Trade unions in oil and gas sector cut across junior staff (National Union of Petroleum and Natural Gas - NUPENG); and senior staff (Petroleum and Natural Gas Senior Staff Association of Nigeria - PENGASSAN). Employers in the oil and gas sector are not unionised but they deal with the national and branch unions on individual basis. The tertiary institutions in the educational sector have three tiers of unions: Junior staff (Non-Academic Staff Union - NASU), senior staff in the universities (Senior Staff Association of Nigeria Universities - SSANU), senior staff in the 
polytechnics (Senior Staff Association of Nigeria Polytechnics - SSANP), academic staff in the universities (Academic Staff Union of Universities - ASUU), academic staff in the polytechnics (Academic Staff Union, of Polytechnics ASUP), academic staff in the colleges education. (Colleges of Education Academic Staff Union - COEASU). The sole employer of the members of these unions is the Federal Government represented by the Federal Ministries of Education and Labour, National Universities Commission, National Commission of Colleges of Education and Office of the Head of Service of the Federation. The questionnaire administered on the sample drawn from both sector was 700 (Seven Hundred).

Both primary and secondary sources of data collection were utilized. For the primary source the questionnaire administered on the sample drawn from both sector was 700 (seven hundred). For secondary sources, reports, journals, periodicals, and other relevant information published as well as unpublished records kept by the Federal Ministry of Labour and Productivity were used and supplemented with data contained in the Central Bank of Nigeria Annual Statistical Bulletin and documentary evidence by Industrial Arbitration Panel (IAP) and National Industrial Court (NIC) respectively.

\subsection{Data Gathering and Analytical Tools}

The data was obtained by means of questionnaire administration. Following the exploratory nature of the study, the fixed choice questions items were analysed using distributive statistics, mean item score (MIS) to measure central tendency and reduce raw data to single score. Chi-square was used to test the independence between the two groups and to evaluate their response to issues raised. T-test was employed to test the independence of means and difference between the two groups while co-efficient of variation was to compare the two measures obtained from the two group and expressed in percentage measures.

Using MIS scale point, 5 for strongly agree (SA), very efficient (VE), very inefficient (VI) and 1 for no opinion (NO) as the case may be, the impact of sanctions on management of trade disputes was operationalised by asking the respondents to provide answers to the following:

(i) Whether parties hold different perception on the effectiveness of trade disputes settlement machineries;

(ii) Rating of the performance of trade disputes settlement machineries;

(iii) Whether parties have lost confidence in the use of trade disputes settlement machineries.

(iv) Their views on how often government apply sanctions to check disputes;

(v) Whether the application of statutory sanctions has reduce the number of disputes reported; and

(vi) Whether the intensification of the use of dialogue and negotiation by parties can reduce dependency on statutory procedures.

\section{Discussion}

One of the findings of the study is that parties hold different perception on the efficacy of the trade disputes settlement machineries. This attests to the view point made by Anyim (2009) that institutional machineries for settling disputes, voluntarily evolved and established or imposed by labour law are thus much a part of the dispute-stimulating process as well as obviously being a means for sorting out disputes. This then suggests that the frequency of disputes at work is traceable equally not only to the conduct of the parties, but also to the disputes settlement process or mechanisms devised by them or imposed by regulatory authorities or both. The foregoing no doubt accounts for difference in the perception of the parties

The second finding focused on the rating of the performance of the trade disputes settlement mechanism which the study found to be inefficient. Consequently, the mechanism has not met its intended purpose by curtailing the number of disputes.

The third finding shows that parties seems to have lost confidence in the usage of the trade disputes settlement mechanism or machineries since it has not minimised the occurrence disputes nor has it made the settlement of disputes flawless Contrary to expectation, disputes from available records have been on the increase on a continuous basis. In sum, parties hold different perception on the effectiveness of the mechanism to the extent that they rated the performance of the mechanism as inefficient and seem to have lost confidence on its usage.

The fourth is a major finding of the study which revealed that government seldom apply statutory sanctions to check disputes and this goes to raise the question on government's sincere intention to foster industrial peace through the creation of the trade disputes settlement machineries. Government's policies sometimes lack creditability and firmness they should have Government in similar vein has consistently breached the legislation on "no work, no pay" (Anyim, 
2009). As Orifowomo (2008) rightly observes, employees especially in the public sector seldom invoke the "no work, no pay” rule, possibly because the employer themselves are usually at fault by their failure to nip a looming strike in the bud. The government as a leader should lead other employers in its policy implementation.

The fifth is also a major finding in which the study found that the imposition of statutory sanctions by government has no significant effect on the number of disputes reported.

The T-test analysis shows there is significant difference between the number of disputes reported before and after the enactment of the Trade Disputes Act, though the coefficient of variation for the two periods show that more disputes were recorded pre than post Act enactment. This trend could be traceable to the state of the economy and not necessarily on the effect of sanction as a variable under consideration. In a chat with an IAP official by this author with respect to breach of statutory sanctions, the official blamed the problem on lack of political will on the part of the government to enforce the provisions of the law. Besides, the fines attached to the offences are not only ridiculous but out of fund with the present day economic realities. He opined that this seems to greatly account for why parties flagrantly breach the law.

The sixth finding revealed that the intensification of the use of dialogue and negotiation by parties will curtail the number of reported disputes and lessen dependency on statutory procedures/since findings had shown that statutory sanctions seem not to have positive or appreciable effect on number of reported disputes.

\section{Recommendations}

(1) There is need for speedy review of fines attached to statutory sanctions to forestall their flagrant breaches and abuses by parties.

(2) Government should allow its policies, directives and pronouncements as leader and regulator in industrial relations practice to be firm, confident and also have finesse. Besides, it should have the political will to implement the sanction(s) even where they are against its wish or not in its favour.

(3) The parties should make strikes and lockouts option the last resort and always work towards the use of dialogue and negotiation to reduce dependency on statutory procedures.

(4) The services rendered by IAP and NIC should be commercialised and made to be at cost to parties in order to discourage disputants from the use of strike but to use internal machineries to minimize disputes and resolve their differences amicably.

(5) The issue of divergent views held by parties on the effectiveness, or otherwise of the trade disputes settlement machineries need to be critically examined with a view to harmonizing the views of all the stakeholders in a bid to make them have genuine faith and confidence in the use of the machineries.

(6) The officials of the Ministry of Labour and Productivity should be trained continuously both locally and internationally to sharpen their skills, enhance their performance and keep them abreast of global trends and challenges in trade disputes management.

(7) The trade unions equally need to embark on capacity building programmes to enhance the skills of their rank and file membership in the art of trade disputes management. There is also the need to implore management to give the unions all necessary assistance on training matters in order to improve labour - management relations that will guarantee industrial peace and harmony in the workplace.

\section{Conclusion}

The Trade Disputes Act has laid down the procedures for expeditious settlement of industrial disputes through the use of voluntary machinery to the external trade disputes settlement machineries. The intention of the Act is make for good industrial relations which will promote industrial peace and harmony and also help to create a social climate in which parties can be expected to contribute to production activities and the industrial progress of the nation.

This study had shown that the statutory a sanctions have no positive effect on the management of trade disputes and the factors responsible for the ineffectiveness of the sanctions were adduced. The study went further to outline suggested remedies to the problem. In a dynamic society, no social policy can remain stagnant. It is on this note that a clarion call is being to government to speedily review all the sections in the Trade Disputes Act that relates to sanctions for the breach of the Act. To leave the issue unaddressed will have consequences that will be damaging to the national economy as industrial strife will remain unchecked and devoid of safety valve. In conclusion, may parties embark on course of action(s) that will minimize trade disputes through the religious observance of the provisions of the Trade dispute Act. 


\section{References}

Anyim, F. C. (2009). A Critique of Trade Disputes Settlement Mechanism in Nigeria: 1968 to 2004. Unpublished Ph.D Thesis, University of Lagos.

Aturu, B. (2001). A Handbook of Nigerian Labour Laws, Lagos, Publication of Friedrich Ebert Stiftung.

Borishade, M. A. (1990). Disputes Machinery and Settlement Procedures Lecture Delivered at an Industrial Relations Workshop Organized by ASSBIFI at the University of Lagos Conference Centre, August, Unpublished.

Fajana, S. (2000). Industrial Relations in Nigeria: Theory and Features, Lagos, Labofin and Company.

Fashoyin, T. (1980). Industrial Relations in Nigeria, Lagos, Longman.

Fashoyin, T. (1992). Industrial Relations in Nigeria, (2 ${ }^{\text {nd }}$ ed), Lagos, Longman Nigeria.

Iwuji, E.C. (1987). Settlement of Trade isputes in Dafe Otobo and M.Omole (eds) Readings in Industrial Relations in Nigeria, Lagos; Malthouse Publishing Ltd.

Odumosu, O. T. (1987). The Trade Union Leader and Resolution of Industrial Conflicts in Dafe, Otobo and M. Omole, Readings in Industrial Relations in Nigeria, Lagos, Malthouse Press Ltd.

Orojo, J. O. \& Ajomo, M. O. (1999). The Law and Practice of Arbitration and conciliation in Nigeria, Lagos, Mbeyi and Associates (Nig) Ltd.

Otobo, D. (1987). Strikes and Lockouts in Nigeria: Some Theoretical Notes in Dafe Otobo and M. Omole (eds) Readings in Industrial Relations in Nigeria. Lagos, Malthouse Publishing.Trade Disputes Act CAP T8 of the Laws of the Federation of Nigeria, 2004.

Otobo, D. (2005). Industrial Relations: Theory and Controversies Lagos, Malthouse Publishing Ltd.

Otobo, D. (2007). Contemporary Industrial Relations in Nigeria in G. Wood and C. Brewster (ed) Industrial Relations in Africa, New York, Palgrave McMillan.

Ubeku, A. K. (1983). Industrial Relations in Developing Countries: the Case of Nigeria, London, McMillan Press

Yesufu, T. M. (1982). The Dynamics of Industrial Relations: the Nigerian Experience, University Press, Ibadan.

Table 1. Sample size and response rate

\begin{tabular}{|c|c|c|c|}
\hline Sector & Sample Drawn & $\begin{array}{c}\text { No } \\
\text { Responding }\end{array}$ & $\begin{array}{c}\text { Percentage } \\
\text { (Response Rate) }\end{array}$ \\
\hline Oil \& Gas & 230 & 185 & 80 \\
\hline Education & 470 & 365 & 78 \\
\hline Total & 700 & 550 & 79 \\
\hline
\end{tabular}

Source: Fieldwork February, 2011. It shows the average response rate to be $79 \%$. On the overall, the response rate is quite high.

Table 2. The data: legend to analyses

\begin{tabular}{|c|c|c|c|}
\hline S/NO & SCALE VALUES & KEYS & MIS SCALE POINTS \\
\hline (A) & & & 5 \\
i & Strongly agree & SA & 4 \\
ii & Agree & A & 3 \\
iii & Disagree & D & 2 \\
iv & Strongly disagree & SD & 1 \\
v & No opinion & NO & 5 \\
\hline (B) & & & 4 \\
i & Very effective & VE & 3 \\
ii & Effective & E & 2 \\
iii & Ineffective & I & 1 \\
iv & Very ineffective & VI & NO \\
V & No opinion & VO \\
\hline (C) & & VO & 5 \\
i & Very often & &
\end{tabular}




\begin{tabular}{|c|c|c|c|}
\hline ii & Often & O & 4 \\
iii & Seldom & S & 3 \\
iv & Not al all & NA & 2 \\
v & No opinion & NO & 1 \\
\hline
\end{tabular}

Table 3. Respondents' view on whether parties hold different perception on the effectiveness of trade disputes settlement machineries

\begin{tabular}{|c|c|c|c|c|c|c|c|c|c|c|c|c|}
\hline \multirow[t]{2}{*}{ Organisation } & \multirow{2}{*}{$\begin{array}{l}\text { Sa } \\
\text { No }\end{array}$} & \multirow[b]{2}{*}{$\%$} & \multirow{2}{*}{$\begin{array}{c}\text { A } \\
\text { No }\end{array}$} & \multirow[b]{2}{*}{$\%$} & \multirow{2}{*}{$\begin{array}{c}\mathrm{D} \\
\text { No }\end{array}$} & \multirow[b]{2}{*}{$\%$} & \multirow{2}{*}{$\begin{array}{l}\text { Sd } \\
\text { No }\end{array}$} & \multirow[b]{2}{*}{$\%$} & \multicolumn{2}{|r|}{ No } & \multicolumn{2}{|c|}{ Total } \\
\hline & & & & & & & & & No & $\%$ & No & $\%$ \\
\hline \multicolumn{13}{|l|}{ Oil \& Gas } \\
\hline Nupeng & 2 & 50 & 58 & 51 & 23 & 38 & 2 & 33 & - & - & 85 & 46 \\
\hline Pengassan & 1 & 25 & 34 & 30 & 22 & 37 & 3 & 50 & - & - & 60 & 33 \\
\hline Employers & 1 & 25 & 22 & 19 & 15 & 25 & 1 & 17 & 1 & 100 & 40 & 21 \\
\hline Total & 4 & 100 & 114 & 100 & 60 & 100 & 6 & 100 & 1 & 100 & 185 & 100 \\
\hline \multicolumn{13}{|l|}{ Education } \\
\hline Asuu & 5 & 29 & 33 & 15 & 14 & 13 & 3 & 18 & - & - & 55 & 15 \\
\hline Asup & 2 & 12 & 24 & 11 & 12 & 11 & 1 & 6 & 1 & 20 & 40 & 11 \\
\hline Coeasu & 3 & 17 & 20 & 9 & 13 & 12 & 2 & 13 & - & - & 38 & 10 \\
\hline Ssanu & 2 & 12 & 44 & 20 & 20 & 18 & 2 & 13 & 2 & 40 & 70 & 19 \\
\hline Ssanp & 1 & 6 & 29 & 13 & 16 & 15 & 3 & 18 & 1 & 20 & 50 & 14 \\
\hline Nasu & 2 & 12 & 47 & 22 & 23 & 21 & 4 & 25 & 1 & 20 & 77 & 21 \\
\hline Employer & 2 & 12 & 21 & 10 & 11 & 10 & 1 & 6 & - & - & 35 & 10 \\
\hline Total & 17 & 100 & 218 & 100 & 109 & 100 & 16 & 100 & 5 & 100 & 365 & 100 \\
\hline
\end{tabular}

Source: Fieldwork, February, 2011

Table 4. MIS and Chi-Square on issue in Table 1

Significant at $\mathrm{P}<0.05$

\begin{tabular}{|c|c|c|l|}
\hline \multicolumn{2}{|c|}{ MIS } & \multicolumn{2}{c|}{ Chi-Square } \\
\hline Oil \& Gas & Education & $\mathrm{X}^{2}$ & Pval \\
\hline 3.61 & 3.16 & 3.512 & .476 (ns) \\
\hline
\end{tabular}

ns $=$ not significant

Table 5. Respondents' rating of the performance of trade disputes machineries

\begin{tabular}{|c|c|c|c|c|c|c|c|c|c|c|c|c|}
\hline \multirow[t]{2}{*}{ Organisation } & \multicolumn{2}{|c|}{ VE } & \multicolumn{2}{|c|}{$\mathrm{E}$} & \multicolumn{2}{|r|}{ I } & \multicolumn{2}{|r|}{ VI } & \multicolumn{2}{|r|}{ NO } & \multicolumn{2}{|c|}{ TOTAL } \\
\hline & $\mathrm{NO}$ & $\%$ & NO & $\%$ & $\mathrm{NO}$ & $\%$ & NO & $\%$ & $\mathrm{NO}$ & $\%$ & NO & $\%$ \\
\hline \multicolumn{13}{|l|}{ Oil \& Gas } \\
\hline Nupeng & 3 & 38 & 29 & 39 & 46 & 49 & 5 & 71 & 2 & 100 & 85 & 46 \\
\hline Pengassan & 2 & 25 & 19 & 25 & 37 & 40 & 2 & 29 & - & - & 60 & 33 \\
\hline Employers & 3 & 38 & 27 & 36 & 10 & 11 & - & - & - & - & 40 & 21 \\
\hline Total & 8 & 100 & 75 & 100 & 93 & 100 & 7 & 100 & 2 & 100 & 185 & 100 \\
\hline \multicolumn{13}{|l|}{ Education } \\
\hline Asuu & 2 & 9 & 14 & 12 & 36 & 17 & 3 & 17 & - & - & 55 & 15 \\
\hline Asup & 3 & 13 & 12 & 10 & 21 & 10 & 4 & 24 & - & - & 40 & 11 \\
\hline Coeasu & 2 & 9 & 13 & 11 & 23 & 11 & - & - & - & - & 38 & 10 \\
\hline Ssanu & 4 & 17 & 20 & 17 & 43 & 21 & 2 & 12 & 1 & 100 & 70 & 19 \\
\hline
\end{tabular}




\begin{tabular}{|c|c|c|c|c|c|c|c|c|c|c|c|c|}
\hline Ssanp & 3 & 13 & 17 & 15 & 29 & 14 & 1 & 6 & - & - & 50 & 14 \\
\hline Nasu & 5 & 22 & 18 & 16 & 47 & 23 & 7 & 41 & - & - & 77 & 21 \\
\hline Employer & 4 & 17 & 22 & 19 & 9 & 4 & - & - & - & - & 35 & 10 \\
\hline Total & 23 & 100 & 116 & 100 & 208 & 100 & 17 & 100 & 1 & 100 & 365 & 100 \\
\hline
\end{tabular}

Source: Fieldwork, February, 2011

Table 6. MIS AND Chi-Square on issue in Table 3

Significant at $\mathrm{P}<0.05$

\begin{tabular}{|c|c|c|l|}
\hline \multicolumn{2}{|c|}{ MIS } & \multicolumn{2}{c|}{ Chi-Square } \\
\hline Oil \& Gas & Education & $\mathrm{X}^{2}$ & Pval \\
\hline 3.37 & 3.39 & 6.257 & $.181(\mathrm{~ns})$ \\
\hline
\end{tabular}

ns $=$ not significant

Table 7. Respondents' view on whether parties have lost confidence in the use of trade disputes settlement machineries

\begin{tabular}{|c|c|c|c|c|c|c|c|c|c|c|c|c|}
\hline \multirow[t]{2}{*}{ Organisation } & \multicolumn{2}{|c|}{ SA } & \multicolumn{2}{|c|}{ A } & \multirow{2}{*}{$\frac{\mathrm{D}}{\mathrm{NO}}$} & \multirow[b]{2}{*}{$\%$} & \multirow{2}{*}{$\frac{\mathrm{SD}}{\mathrm{NO}}$} & \multirow[b]{2}{*}{$\%$} & \multirow{2}{*}{$\frac{\mathrm{NO}}{\mathrm{NO}}$} & \multirow[b]{2}{*}{$\%$} & \multicolumn{2}{|c|}{ TOTAL } \\
\hline & NO & $\%$ & NO & $\%$ & & & & & & & $\begin{array}{l}\mathrm{N} \\
\mathrm{O} .\end{array}$ & $\%$ \\
\hline \multicolumn{13}{|l|}{ Oil \& Gas } \\
\hline Nupeng & 5 & 63 & 52 & 49 & 26 & 41 & 2 & 29 & - & - & 85 & 46 \\
\hline Pengassan & 3 & 37 & 39 & 38 & 15 & 24 & 3 & 42 & - & - & 60 & 33 \\
\hline Employers & - & - & 15 & 14 & 22 & 35 & 2 & 29 & 1 & 100 & 40 & 21 \\
\hline Total & 8 & 100 & 106 & 100 & 63 & 100 & 7 & 100 & 1 & 100 & $\begin{array}{c}18 \\
5\end{array}$ & 100 \\
\hline \multicolumn{13}{|l|}{ Education } \\
\hline Asuu & 1 & 7 & 38 & 19 & 15 & 12 & 1 & 5 & - & - & 55 & 15 \\
\hline Asup & - & - & 20 & 10 & 15 & 12 & 5 & 25 & - & - & 40 & 11 \\
\hline Coeasu & 3 & 20 & 22 & 11 & 11 & 9 & 1 & 5 & 1 & 33 & 38 & 10 \\
\hline Ssanu & 5 & 33 & 43 & 21 & 19 & 16 & 3 & 15 & - & - & 70 & 19 \\
\hline Ssanp & 2 & 13 & 27 & 13 & 16 & 13 & 3 & 15 & 2 & 67 & 50 & 14 \\
\hline Nasu & 3 & 20 & 48 & 23 & 21 & 17 & 5 & 25 & - & - & 77 & 21 \\
\hline Employer & 1 & 7 & 7 & 3 & 25 & 20 & 2 & 10 & - & - & 35 & 10 \\
\hline Total & 15 & 100 & 205 & 100 & 122 & 100 & 20 & 100 & 3 & 100 & $\begin{array}{c}36 \\
5\end{array}$ & 100 \\
\hline
\end{tabular}

Source: Fieldwork, February, 2011

Table 8. MIS AND Chi-Square on issue in Table 5

Significant at $\mathrm{P}<0.05$

\begin{tabular}{|c|c|c|l|}
\hline \multicolumn{2}{|c|}{ MIS } & \multicolumn{2}{c|}{ Chi Square } \\
\hline Oil \& Gas & Education & $\mathrm{X}^{2}$ & Pval \\
\hline 3.61 & 3.57 & 0.909 & $.923(\mathrm{~ns})$ \\
\hline
\end{tabular}

ns $=$ not significant 
Table 9. Respondents' view on how often government apply sanctions to check disputes

\begin{tabular}{|c|c|c|c|c|c|c|c|c|c|c|c|c|}
\hline \multirow[t]{2}{*}{ Organisation } & \multicolumn{2}{|c|}{$\mathrm{VO}$} & \multicolumn{2}{|c|}{0} & \multicolumn{2}{|c|}{$\mathrm{S}$} & \multicolumn{2}{|r|}{ NA } & \multicolumn{2}{|r|}{$\mathrm{NO}$} & \multicolumn{2}{|c|}{ TOTAL } \\
\hline & $\mathrm{NO}$ & $\%$ & NO & $\%$ & $\mathrm{NO}$ & $\%$ & NO & $\%$ & NO & $\%$ & NO & $\%$ \\
\hline \multicolumn{13}{|l|}{ Oil \& Gas } \\
\hline Nupeng & - & - & 21 & 43 & 61 & 47 & 3 & 60 & - & - & 85 & 46 \\
\hline Pengassan & - & - & 16 & 33 & 42 & 32 & 2 & 40 & - & - & 60 & 33 \\
\hline Employers & - & - & 12 & 24 & 28 & 21 & - & - & - & - & 40 & 21 \\
\hline Total & - & - & 49 & 100 & 131 & 100 & 5 & 100 & - & - & 185 & 100 \\
\hline \multicolumn{13}{|l|}{ Education } \\
\hline Asuu & - & - & 12 & 11 & 43 & 18 & - & - & - & - & 55 & 15 \\
\hline Asup & - & - & 11 & 10 & 29 & 12 & - & - & - & - & 40 & 11 \\
\hline Coeasu & 2 & 22 & 10 & 9 & 23 & 10 & 2 & 40 & 1 & 33 & 38 & 10 \\
\hline Ssanu & 3 & 33 & 21 & 19 & 46 & 19 & - & - & - & - & 70 & 19 \\
\hline Ssanp & 1 & 11 & 19 & 17 & 29 & 12 & 1 & 20 & - & - & 50 & 14 \\
\hline Nasu & 3 & 33 & 21 & 19 & 49 & 20 & 2 & 40 & 2 & 67 & 77 & 21 \\
\hline Employer & - & - & 16 & 15 & 19 & 8 & - & - & - & - & 35 & 10 \\
\hline Total & 9 & 100 & 110 & 100 & 238 & 100 & 5 & 100 & 3 & 100 & 365 & 100 \\
\hline
\end{tabular}

Source: Fieldwork, February, 2011

Table 10. MIS AND Chi-Square on issue in Table 7

Significant at $\mathrm{P}<0.05$

\begin{tabular}{|c|c|c|l|}
\hline \multicolumn{2}{|c|}{ MIS } & \multicolumn{2}{c|}{ Chi-square } \\
\hline Oil \& Gas & Education & $\mathrm{X}^{2}$ & Pval \\
\hline 3.23 & 3.32 & 8.514 & $.074(\mathrm{~ns})$ \\
\hline
\end{tabular}

ns $=$ not significant

Table 11. Number of trade disputes reported PRE- and POST- ACT enactment

\begin{tabular}{|c|c|c|c|}
\hline \multicolumn{2}{|c|}{ PRE-ACT } & \multicolumn{2}{c|}{ POST-ACT } \\
\hline YEAR & NO OF DISPUTES & YEAR & NO OF DISPUTES \\
\hline 1968 & 132 & 1977 & 172 \\
\hline 1969 & 163 & 1978 & 142 \\
\hline 1970 & 165 & 1979 & 155 \\
\hline 1971 & 296 & 1980 & 355 \\
\hline 1972 & 196 & 1981 & 258 \\
\hline 1973 & 173 & 1982 & 341 \\
\hline 1974 & 338 & 1983 & 184 \\
\hline 1975 & 775 & 1984 & 100 \\
\hline 1976 & 230 & 1985 & 77 \\
\hline TOTAL & 2468 & TOTAL & 1784 \\
\hline
\end{tabular}

Source: Compiled from records of Federal Ministry of Labour and Productivity and CBN Annual Statistical Bulletin. (Various years).

Table 12. T-test for number of disputes reported in PRE and POST trade disputes act enactment

\begin{tabular}{|l|l|l|l|l|l|c|}
\hline SN & PARAMETER & Mean & SD & t-value & Df & Sig level \\
\hline A & Pre-Act enactment & 264.0000 & 190.77969 & 1.266 & 18 & $.222(\mathrm{~ns})$ \\
\hline B & $\begin{array}{l}\text { Post-Act } \\
\text { Enactment }\end{array}$ & 176,4000 & 107.22168 & 1.266 & 14.17 & $.226(\mathrm{~ns})$ \\
\hline
\end{tabular}


Significant at $\mathrm{P}<0.05$

Result: There is no significant difference in number of disputes reported within the two periods

CO-EFFICIENT OF VARIATION (CV) (PRE AND POST ACT) ENACTMENT

$\mathrm{CV}^{1}$ (Pre-Act) $=\frac{190.77969}{264.0000} \quad \mathrm{x} 100=72.26 \%$

$\mathrm{CV}^{2}($ Post Act $)=\quad=\underline{107.22168} \times 100=60.78 \%$

176.4000

Result:

$\mathrm{CV}^{1}>\mathrm{CV}^{2}$ i.e. more disputes were reported pre-act than post-act.

Table 13. Respondents' view on whether the application of statutory sanctions has reduced the number of disputes reported

\begin{tabular}{|c|c|c|c|c|c|c|c|c|c|c|c|c|}
\hline \multirow[t]{2}{*}{ Organisation } & \multicolumn{2}{|c|}{ SA } & \multicolumn{2}{|c|}{ A } & \multicolumn{2}{|c|}{$\mathrm{D}$} & \multicolumn{2}{|r|}{ SD } & \multicolumn{2}{|r|}{$\mathrm{NO}$} & \multicolumn{2}{|c|}{ TOTAL } \\
\hline & $\mathrm{NO}$ & $\%$ & NO & $\%$ & $\mathrm{NO}$ & $\%$ & $\mathrm{NO}$ & $\%$ & $\mathrm{NO}$ & $\%$ & $\mathrm{NO}$ & $\%$ \\
\hline \multicolumn{13}{|l|}{ Oil \& Gas } \\
\hline \multicolumn{13}{|l|}{ Nupeng } \\
\hline Pengassan & 3 & 60 & 18 & 35 & 37 & 30 & 2 & 50 & - & - & 60 & 33 \\
\hline Employers & 1 & 20 & 14 & 27 & 24 & 19 & 1 & 25 & - & - & 40 & 21 \\
\hline Total & 5 & 100 & 51 & 100 & 125 & 100 & 4 & 100 & - & - & 185 & 100 \\
\hline \multicolumn{13}{|l|}{ Education } \\
\hline Asuu & - & - & 16 & 15 & 39 & 17 & - & - & - & - & 55 & 15 \\
\hline Asup & 2 & 10 & 13 & 12 & 22 & 9 & $\mathrm{~L}$ & 17 & 1 & 25 & 40 & 11 \\
\hline Coeasu & 2 & 10 & 11 & 11 & 24 & 11 & 1 & 8 & - & - & 38 & 10 \\
\hline Ssanu & 8 & 38 & 17 & 17 & 43 & 19 & 1 & 8 & 1 & 25 & 70 & 19 \\
\hline Ssanp & 4 & 19 & 15 & 15 & 29 & 13 & 2 & 17 & - & - & 50 & 14 \\
\hline Nasu & 3 & 14 & 20 & 20 & 49 & 22 & 3 & 25 & 2 & 50 & 77 & 21 \\
\hline Employer & 2 & 10 & 10 & 10 & 20 & 9 & 3 & 25 & - & - & 35 & 10 \\
\hline Total & 21 & 100 & 102 & 100 & 226 & 100 & 12 & 100 & 4 & 100 & 365 & 100 \\
\hline
\end{tabular}

Source: Fieldwork, February, 2011

Table 14. MIS and Chi-Square on issue in Table 9

Significant at $\mathrm{P}<0.05$

\begin{tabular}{|c|c|c|l|}
\hline \multicolumn{2}{|c|}{ MIS } & \multicolumn{2}{c|}{ Chi-square } \\
\hline Oil \& Gas & Education & $\mathrm{X}^{2}$ & Pval \\
\hline 3.30 & 3.33 & 5.599 & $.231(\mathrm{~ns})$ \\
\hline
\end{tabular}

$\mathrm{ns}=$ not significant 
Table 15. Respondents' view on whether the intensification of the use of dialogue and negotiation by parties can reduce dependency on statutory procedures

\begin{tabular}{|c|c|c|c|c|c|c|c|c|c|c|c|c|}
\hline \multirow[t]{2}{*}{ Organisation } & \multicolumn{2}{|c|}{ SA } & \multicolumn{2}{|c|}{ A } & \multicolumn{2}{|c|}{$\mathrm{D}$} & \multicolumn{2}{|l|}{$\mathrm{SD}$} & & NO & \multicolumn{2}{|c|}{ TOTAL } \\
\hline & NO & $\%$ & NO & $\%$ & NO & $\%$ & NO & $\%$ & $\begin{array}{c}\mathrm{N} \\
0\end{array}$ & $\%$ & NO & $\%$ \\
\hline \multicolumn{13}{|l|}{ Oil \& Gas } \\
\hline Nupeng & 28 & 31 & 49 & 62 & 5 & 50 & 3 & 60 & - & - & 85 & 46 \\
\hline Pengassan & 35 & 39 & 21 & 27 & 2 & 20 & 1 & 20 & 1 & 50 & 60 & 33 \\
\hline Employers & 26 & 29 & 9 & 11 & 3 & 30 & 1 & 20 & 1 & 50 & 40 & 21 \\
\hline Total & 89 & 100 & 79 & 100 & 10 & 100 & 5 & 100 & 2 & 100 & 185 & 100 \\
\hline \multicolumn{13}{|l|}{ Education } \\
\hline Asuu & 37 & 16 & 16 & 15 & 2 & 10 & - & - & - & - & 55 & 15 \\
\hline Asup & 30 & 13 & 8 & 6 & 2 & 10 & - & - & - & - & 40 & 11 \\
\hline Coeasu & 23 & 10 & 13 & 12 & 1 & 5 & 1 & 17 & - & - & 38 & 10 \\
\hline Ssanu & 42 & 18 & 24 & 23 & 3 & 15 & 1 & 17 & - & - & 70 & 19 \\
\hline Ssanp & 32 & 14 & 14 & 13 & 2 & 10 & 1 & 17 & 1 & 33 & 50 & 14 \\
\hline Nasu & 47 & 20 & 19 & 18 & 7 & 35 & 2 & 33 & 2 & 67 & 77 & 21 \\
\hline Employer & 19 & 8 & 12 & 11 & 3 & 15 & 1 & 17 & - & - & 35 & 10 \\
\hline Total & 230 & 100 & 106 & 100 & 20 & 100 & 6 & 100 & 3 & 100 & 365 & 100 \\
\hline
\end{tabular}

Source: Fieldwork, February, 2011

Table 16. MIS and Chi-Square on issue in Table 11

Significant at $\mathrm{P}<0.05$

\begin{tabular}{|c|c|c|l|}
\hline \multicolumn{2}{|c|}{ MIS } & \multicolumn{2}{c|}{ Chi-square } \\
\hline Oil \& Gas & Education & $\mathrm{X}^{2}$ & Pval \\
\hline 4.34 & 4.51 & 12.892 & $.012(\mathrm{~ns})$ \\
\hline
\end{tabular}

ns $=$ not significant 